\title{
KISAH NABI IBRÂHÎM DALAM ALQURAN (PERSPEKTIF PENDIDIKAN ISLAM)
}

\author{
Sari Kumala \\ Dosen UNISKA, Banjarmasin, Indonesia \\ Sarikumala.86@gmail.com
}

\begin{abstract}
Pendidikan Islam sangat memperhatikan perenungan atas kisah tertentu dan dalam pengambilan ibrah. Umat Nabi Muhammad hendaknya mengikuti ajaran nabi Ibrâhîm seorang yang hanif dan tidak mempersekutukan Allah. Ini penelitian kualitatif yang menggunakan pendekatan pustaka (library research). Cerita nabi Ibrâhîm ditelusuri pada ayat-ayat cerita Nabi Ibrâhîm dengan metode tafsir maudhu'i atau tematik.

Ibrah yang bisa diambil dari Kisah Nabi Ibrâhîm 'Alaihissalâm adalah: a). Selalu sabar, santun, tegar dan tabah dalam menyampaikan dakwah serta yakin akan kebesaran Allah, b). Selalu membiasakan diri mencintai Allah, ridha, ikhlas dan husnuzzan kepada Allah Subhânahu wa Ta'alâ. c). Di hidup dan kehidupan kita harus selalu berikhtiar, bertawakkal dan berdoa dalam menjalankan perintah maupun larangan-larangan Allah Subhânahu wa Ta'alâ.

Aspek pendidikan Islam yang terdapat dalam kisah Nabi Ibrâhîm 'Alaihissalâm dalam Alquran adalah: a). Tujuan pendidikan Nabi Ibrâhîm yaitu menjadi imam para muttaqin dan muslim yang taat dan patuh kepada Allah. b). Peserta didik yaitu kerabat dekat dan kaumnya. c). Pendidik yaitu Nabi Ibrâhîm langsung menyampaiakan dakwah beliau. d). Materi yang disampaikan Nabi Ibrâhîm yaitu tentang tauhid, Ibadah dan tazkiyatunnufûs serta Akhlak. e). Metode dakwah Nabi Ibrahim dengan metode hikmah, mau'izatul hasanah dan mujadalah billati hiya ahsan. f). Lingkungan dakwah Nabi Ibrâhîm 'Alaihissalâm dengan kondisi masyarakat yang meyembah berhala beliau tetap gigih memperjuangkan agama tauhid.

Kisah nabi Ibrâhîm bisa dijadikan sebagai pedoman orangtua untuk bekal pembelajaran tauhid. Ajaran ketauhidan seharusnya sudah ditanamkan sejak usia dini agar orangtua tidak khawatir tentang ketauhidan anakanaknya ketika sudah dewasa.
\end{abstract}

Keywords: Alquran, Pendidikan, Kisah, Ibrâhîm.

\section{A. Pendahuluan}

Pendidikan Islam adalah usaha orang dewasa muslim yang bertakwa secara sadar mengarahkan dan membimbing pertumbuhan serta perkembangan fitrah (kemampuan dasar) anak didik melalui ajaran Islam kearah titik maksimal 
pertumbuhan dan perkembangannya. ${ }^{1}$ Kehadiran Alquran telah memberi pengaruh yang luar biasa bagi lahirnya berbagai konsep yang diperlukan manusia dalam berbagai bidang kehidupan. Kaum muslimin sendiri dalam rangka memahaminya telah melahirkan beribu-ribu kitab yang berupaya menjelaskan makna pesannya. ${ }^{2}$ Telah diyakini bahwa Alquran berisi petunjuk bagi manusia. Ajaran-ajarannya bersifat variatif serta dikemas sedemikian rupa. Ada yang berupa informasi perintah dan larangan, dan ada juga yang dimodifikasi dalam bentuk deskripsi kisah-kisah yang mengandung Ibrah. ${ }^{3}$

Nabi Ibrahim adalah seorang imam yang dijadikan teladan, Ia patuh kepada Allah dan hanif (seorang yang selalu berpegang kepada kebenaran dan tak pernah meninggalkan Allah) dan Ia tidak mempersekutukan Allah. Oleh karena itu, umat Nabi Muhammad diperintahkan untuk mengikuti ajaran Nabi Ibrahim.

Penulis tertarik untuk mengkaji lebih jauh tentang kisah Nabi Ibrâhîm dalam Alquran pada persfektif pendidikan Islam dengan mengambil ibrah dari kisah beliau dalam kehidupan dan aspek pendidikan apa saja yang terdapat didalamnya.

\section{B. Kajian Teori}

\section{Dakwah Nabi Ibrâhîm 'Alaihissalâm kepada Ayah dan Kaumnya}

Sewaktu kecil Ibrâhîm sering melihat ayahnya membuat patungptung tersebut, lalu dia berusaha mencari kebenaran agama yang dianuti oleh keluarganya itu, ini tercantum dalam ayat berikut ini:

\footnotetext{
${ }^{1}$ M.Arifin, Ilmu Pendidikan Islam (Jakarta: Bumi Aksara,2003)h.22

${ }^{2}$ Said Agil Husin Al-Munawwar, Aktualisasi Nilai-Nilai al-Qur'an, dalam Sistem Pendidikan Islam, (Ciputat, PT. Ciputat Press, 2005), h.3

${ }^{3}$ Muhammad Chirzin, Al-Qur'an dan Ulumul Qur'an (Yogyakarta: Dhani Bhakti Prima Yasa, 2003), h. 117
}

Jurnal Ilmiah AL-MADRASAH, Vol. 2, No. 2, Januari-Juni 2018 
Q.S. Al-an'âm/6: 74-764

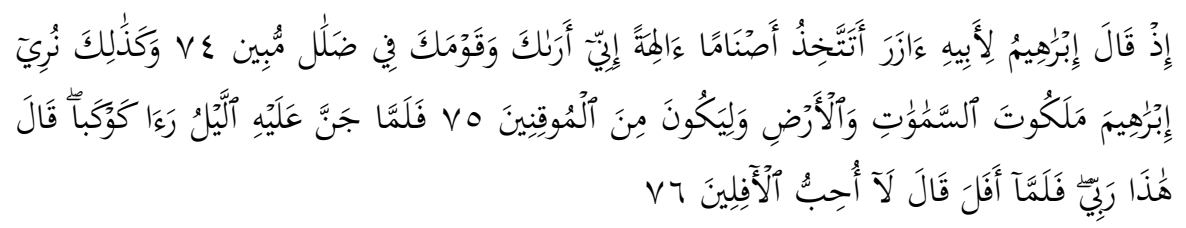

Ibrâhîm menasehati ayahnya tentang penyembahan yang dilakukannya terhadap berhala-berhala, mengingatkan sekaligus melarangnya melakukan hal tersebut, namun ayahnya tidak juga berhenti dari perbuatannya itu, sebagaimana Firman Allah "Dan (ingatlah) di waktu Ibrâhîm berkata kepada bapaknya Azar; pantaskah kamu menjadikan berhala-berhala sebagai ilâh-ilâh" apakah kamu meng-ilâh-kan berhala Allah? "Sesunggunya akau melihat engkau dan kaummu" yaitu orang-orang yang menempuh jalanmu "dalam kesesatan yang nyata" tersesat dan tidak mendapatkan petunjuk kemana mereka harus berjalan, bahkan mereka berada dalam kebingungan dan kebodohan, hal itu jelas bagi orang yang berakal sehat. $^{5}$

Q.S. Al-'an'âm/6: $77^{6}$

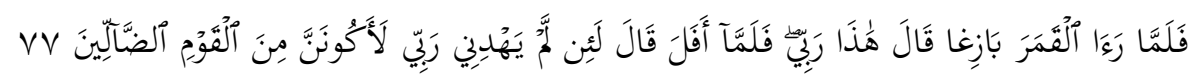

Maka tatkala dia melihat bulan terbit; "Inikah Tuhanku". Cahayanya lebih merata dari pada bintang. Tatkala bulan terbit cahaya bintang pun mulai pudar. Tetapi tentu bumi berputar terus dan alam pun beredar, dan tentu bulan pun akan hilang ke balik ufuk dan kian sehari sesudah purnamanya dia pun akan susut. " Sesudah bulan itu hilang, dia berkata;

\footnotetext{
${ }^{4}$ Tim Penterjemah Departemen Agama RI, Alquran dan Terjemah (Semarang: PT. Tanjung Mas Inti, 1995), h. 199 289

${ }^{5}$ Ibnu Katsir, Tafsirul Qur'anil Adzim, Jilid 3 (Dar Tayyibah: 1999), h. 288-

${ }^{6}$ Tim Penterjemah Departemen Agama RI, Alquran h. 199

${ }^{7}$ Abdul Malik Karim Amrullah, Tafsir... ........h. 361
}

Jurnal Ilmiah AL-MADRASAH, Vol. 2, No. 2, Januari-Juni 2018 
"jika tidaklah aku ditunjuki oleh Tuhanku, niscaya jadilah aku dari kaum yang tersesat" setelah bulan hilang keinsafan yang timbul pada Ibrâhîm lebih hebat daripada keinsafan tatkala bintang tadi hilang. Kalau Allah tidak menunjukinya, merasalah dia bahwa dia akan sesat dibawa oleh khayalnya sendiri. ${ }^{8}$

Q.S. Al-an'âm/6: 78-799

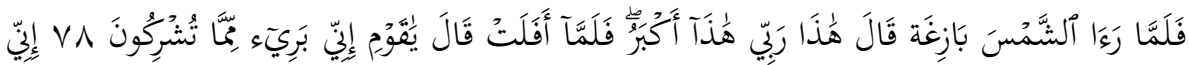

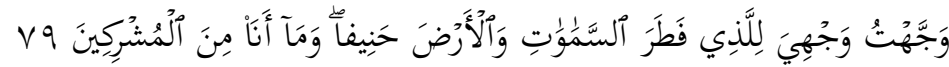

Setelah bulan pun tidak memuaskannya, dia mengarahkan pandangannya kepada matahari. "Kemudian, tatkala dia melihat" dengan mata kepalanya "matahari terbit" di pagi hari, "dia berkata; Inikah" dia "Tuhanku" karena "ini yang lebih besar" dari pada bulan dan bintangbintang dalam pandangan mata telanjang. "Maka" akan tetapi, "tatkala ia" yakni matahari itu "telah terbenam" yakni dikalahkan cahayanya oleh kegelapan malam, dia berkesimpulan sebagaimana kesimpulannya ketika melihat bintang dan bulan tenggelam dan "dia berkata; hai kaumku, sesungguhnya aku berlepas diri dari" penyembahan bintang, bulan, matahari dan "apa saja yang kamu persekutukan" dengan Tuhan Yang Maha Esa, Tuhan Yang Sesungguhnya. ${ }^{10}$

Lalu pada ayat selanjutnya Nabi Ibrâhîm berkata "Aku menghadapkan wajahku dalam keadaan hanîfan yaitu cenderung kepada agama yang benar, dan aku bukanlah termasuk orang-orang yang mempersekutukan Tuhan. ${ }^{11}$

\footnotetext{
${ }^{8}$ Ibidh, h. 362

${ }^{9}$ Tim Penterjemah Departemen Agama RI, Alquran......., h. 199

${ }^{10}$ M. Quraish Shihab, Tafsir ............ h. 516

${ }^{11}$ Ibid, h. 516
}

Jurnal Ilmiah AL-MADRASAH, Vol. 2, No. 2, Januari-Juni 2018 
Q.S. Al-anbiyâ'/21: 55-5912

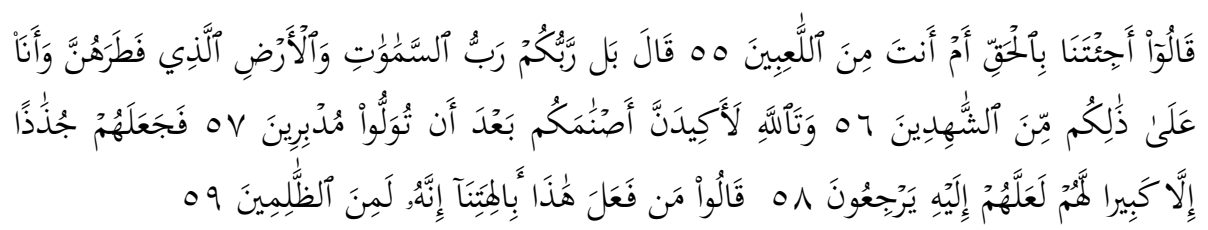

Ibrâhîm menyodorkan perkataan-perkataan dialogis argumentatif semacam itu kepada mereka, sehingga sampailah ia pada tujuannya, yaitu menghinakan patung-patung mereka dan memenangkan agama Allah yang hak, serta menyalahkan semua tindakan mereka yang melakukan pemujaan dan penyembahan terhadap patung-patung tersebut yang memang sudah seharusnya untuk dihancurkan dan dihinakan.

Q.S. Al-anbiyâ'/21 : 60-67 13

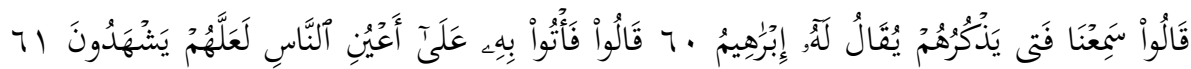

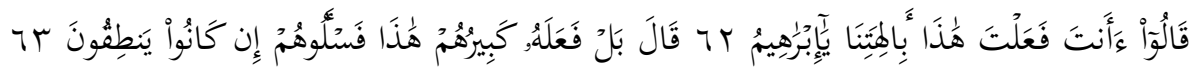

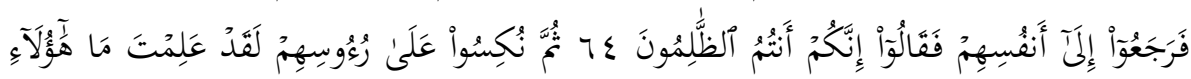

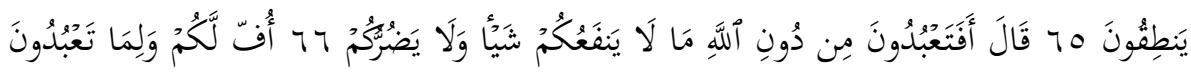

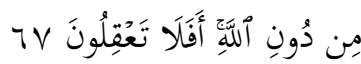

Yakni orang yang mencela dan menghina berhala-berhala mereka bernama Ibrâhîm. Kalau demikian, cari dan bawalah dia kemari ditempat penghacuran tuhan-tuhan kita dan di hadapan mata manusia sehingga dia dapat dilihat orang banyak agar mereka menyaksikan bahwa memang Ibrâhîm yang sering melecehkan tuhan-tuhan itu atau memang dia yang melakukan penghancuran itu. Setelah menemukan Ibrâhîm dan membawanya ke hadapan pemuka-pemuka masyarakat penyembah berhala, mereka bertanya kepada Nabi Ibrâhîm: Apakah engkau yang melakukan perbuatan ini terhadap tuhan-tuhan kami, wahai Ibrâhîm? Dia menjawab:

\footnotetext{
${ }^{12}$ Tim Penterjemah Departemen Agama RI, Alquran .........., h. 502

${ }^{13}$ Ibid, h. $502-503$
}

Jurnal Ilmiah AL-MADRASAH, Vol. 2, No. 2, Januari-Juni 2018 
sebenarnya yang telah melakukannya adalah yang besar dari mereka ini sambil menunjuk kepada patung yang tidak dihancurkannya, maka tanyakanlah kepada mereka, yakni tuhan-tuhan kamu yang lain, baik yang telah hancur berantakan maupun yang masih utuh. Jika mereka dapat berbicara tentulah mereka menyampaikan siapa yang menghancurkan ${ }^{14}$.

Mulailah timbul fikiran dalam diri mereka masing-masing bahwa itu tidak mungkin. Jika ditanyai berhala-berhala itu sudah terang tidak ada satu juga yang akan menjawab, sebab semua hanya benda yang tidak bernyawa. "Sesungguhnya kamulah orang-orang yang zalim" inilah kelanjutan dari kata-kata mereka setelah mereka kembali kepada diri mereka masing-masing tetapi meskipun semua sudah mengerti bahwa perbuatan mereka menyembah berhala itu adalah perbuatan zalim, gelap dan bodoh, namun Ibrâhîm juga yang salah! ${ }^{15}$

Q.S. Al-anbiyâ'/21: $68-70^{16}$

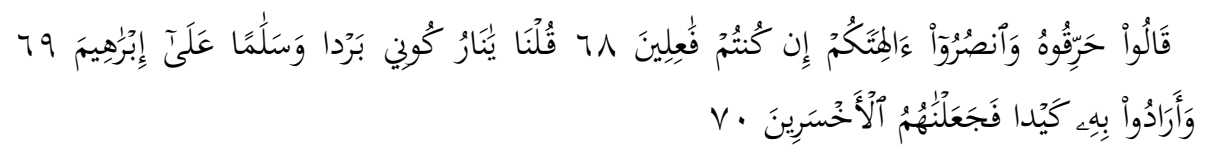

Ketika hujjah-hujjah mereka telah dikalahkan, telah jelas kelemahan mereka, kebenaran telah tampak dan kebathilan telah hancur, mereka pun mencoba berkilah dengan menggunakan kekuasaan mereka. Mereka berkata: "Bakarlah dia dan bantulah ilah-ilah kalian jika kalian orang-orang yang berbuat.” Lalu, mereka mengumpulkan kayu bakar yang banyak sekali. Ketika mereka melemparkannya, Nabi Ibrâhîm 'Alaihissalâm berdoa: hasbiyallâhu wa ni'mal wakîl.

${ }^{14}$ M. Quraish Shihab, Tafsir........, V. 8 h. 79
${ }^{15}$ Abdul Malik Karim Amrullah, Tafsir Al Azhar juz $17 \ldots \ldots \ldots$.... h. 65
${ }^{16}$ Tim Penterjemah Departemen Agama RI, Alquran .........., h. 503

Jurnal Ilmiah AL-MADRASAH, Vol. 2, No. 2, Januari-Juni 2018 
Q.S. Maryam/19: 42-45. ${ }^{17}$

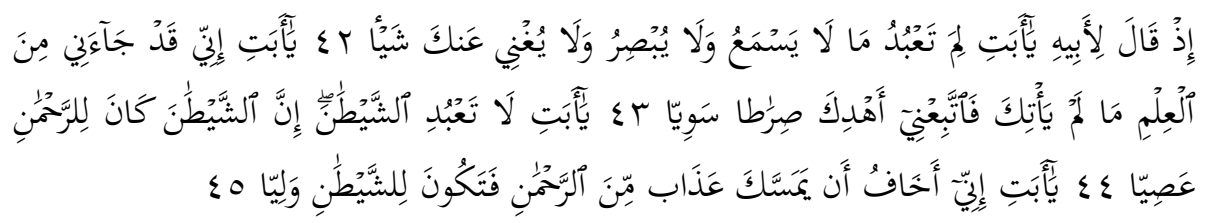

Ketika Nabi Ibrâhîm 'Alaihissalâm berkata dengan lemah lembut kepada bapaknya. Nabi Ibrâhîm 'Alaihissalâm. Pada ayat ini tidak secara tegas menyebut berhala-berhala sebagai sembahan orangtuanya, tetapi menyebut sifatnya, yakni tidak dapat mendengar dan melihat sehingga dengan demikian, beliau sekaligus membuktikan bahwa apa yang disembahnya itu sama sekali batil dan tidak beralasan ${ }^{18}$.

Q.S. Maryam/19: $46^{19}$

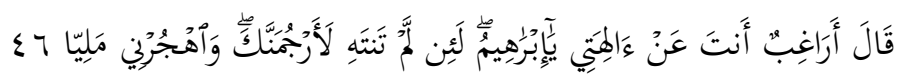

Apabila menurut ilmu engkau tuhanku yang banyak itu tidak patut disembah dan tidak patut dipuja, janganlah engkau tunjukkan juga kebencianmu kepadanya. Tuhan-tuhanku selalu engkau maki, engkau cela dan engkau tunjukkan cacatnya; itu berarti bahwa engkau benci. Kalau engkau tidak suka berdiam dirilah, dan hentikanlah mencela-cela itu. "jika engkau tidak berhenti" daripada mencela dan menunjukkan kekurangankekurangan yang ada pada tuhan-tuhan yang aku sembah itu: "Niscaya akan aku rajam engkau" aku lempari dengan batu. ${ }^{20}$

Q.S. Maryam/19: 47-48

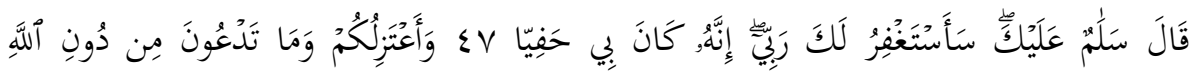

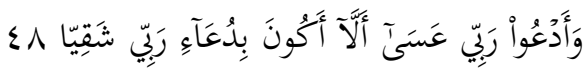

${ }^{17}$ Tim Penterjemah Departemen Agama RI, Alquran.......,h. 467

${ }^{18}$ M. Quraish Shihab, Tafsir Al Misbah......... V. 7, h. 461

${ }^{19}$ Tim Penterjemah Departemen Agama RI, Alquran......., h. 467

${ }^{20}$ Abdul Malik Karim Amrullah, Tafsir .........., h. 42

${ }^{21}$ Tim Penterjemah Departemen Agama RI, Alquran..........., h. 468

Jurnal Ilmiah AL-MADRASAH, Vol. 2, No. 2, Januari-Juni 2018 
Ibrâhîm telah menyambut perkataan ayahnya dengan budi yang luhur pula, budi pekerti seorang hamba Allah Tuhan Yang Maha Rahman dan Dia pun berjanji pula: "Aku akan memohonkan ampun untuk engkau kepada tuhanku” Ibrâhîm telah menyambut bantahan ayahnya dengan dada lapang, hormat dan khidmat seorang anak kepada ayah, diucapkannya salam dimohonkannya ampun buat beliau. Dia percaya benar bahwa permohonan ampunannya kepada Tuhan untuk ayahnya niscaya akan dikabulkan Tuhan: "karena sesungguhnya Dia terhadap kepadaku adalah sangat baik"22

Dalam mempelajari perjalanan hidup Nabi Ibrâhîm 'Alaihissalâm Hal-hal yang dapat diambil ibrah terdapat dalam beberapa moment, diantaranya:

Pertama. Dakwah tauhid Nabi Ibrâhîm 'alaihissalâm kepada ayah dan kaumnya dengan sabar dan penuh santun. Sabar dan santun Nabi Ibrâhîm inilah yang menjadi titik balik yang harus kita teladani selama hidup bagaimana beliau berjuang menyampaikan ajaran tauhid kepada kaum-kaumnya bahkan orangtuanya sendiri, yang mana penuh dengan rintangan dan halangan. Disnilah Allah memberi berbagai keutamaan atau mukjizat supaya Nabi Ibrâhîm yakin akan kebenaran ajaran yang disampaikannya.

Kedua. Nabi Ibrâhîm 'Alaihissalâm Tegar dan Tabah Menghadapi Ujian dan Siksaan. Sikap ini tercermin dalam kisah beliau saat berdakwah mengajak manusia untuk bertauhid dan mengesakan Allah Subhânahu wa Ta'alâ namun kebanyakan menolaknya dengan penuh kenistaan.

Ketiga. Yakin akan kebesaran Allah Pada saat Nabi Ibrâhîm diletakkan di ujung manjaniq ${ }^{23}$, Ia dalam keadaan terbelenggu dengan tangan di belakang. Kemudian kaumnya melemparkan Nabi Ibrâhîm

\footnotetext{
${ }^{22}$ Abdul Malik Karim Amrullah ,Tafsir..........., h. 42-43

${ }^{23}$ Manjanîq, ialah alat pelempar batu besar jarak jauh. Lihat al-Mu’jamulWasith, hlm. 131 dan 140.
}

Jurnal Ilmiah AL-MADRASAH, Vol. 2, No. 2, Januari-Juni 2018 
'Alaihissalâm ke dalam api, dan ia pun berkata: "Cukuplah Allah Azza wa Jalla bagi kami, dan Dia sebaik-baik Penolong”.

\section{Penyembelihan Nabi Ismail sebagai Simbol Keikhlasan}

Disaat umur semakin uzur beliau memohon anak keturunan untuk dapat melanjutkan tugas kenabian namun Allah mengujinya dengan ujian yang sangat berat. Itulah ujian yang penuh dengan kebijaksanaan Allah dan penuh dengan Kasih Sayang-Nya. Sebagaimana Allah paparkan dalam beberapa ayat alquran:

Q.S. Ash-Shâffât//37: 99 - $102^{24}$

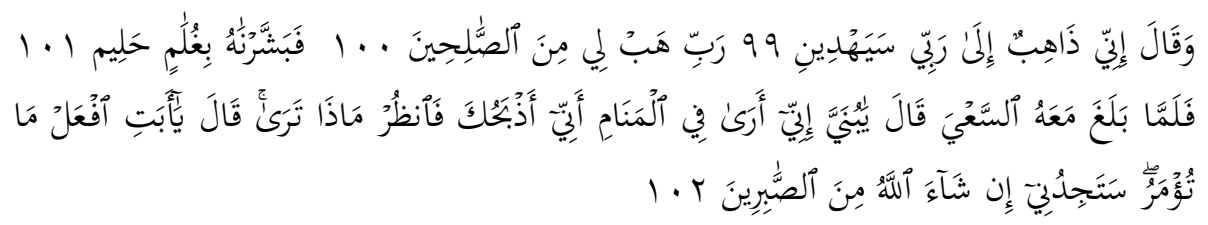

Nabi Ibrâhîm hendak pergi kepada Tuhannya artinya hendak hijrah. Dalam cita-citanya menyediakan hidup untuk menyerahkan diri kepada Tuhan tetapi belum memiliki anak sehingga nabi berdoa pada ayat 100 lalu Nabi Ibrâhîm menikah dengan Hajar dan Sarah. Kemudian di usia 86 tahun Nabi Ibrâhîm dan Siti Hajar melahirkan anak laki-laki bernama Ismail. Kemudian ampai usia 10-15 tahun betapa tertumpah kasih sayang Ibrâhîm kepada anaknya dan pada usia tersebut Nabi Ibrâhîm menyampaiakan pada Nabi Ismail bahwa beliau bermimpi menyembelih anaknya dan disuruhnya untuk memikirkan mimpinya itu dan diharap anaknya menyatakan pendapat. Ismail percaya bahwa mimpi ayahnya adalah wahyu dari Allah bukan mimpi sembarang mimpi sebab itu dianjurkannya ayahnya melaksanakan apa yang diperintahkan. ${ }^{25}$

Q.S. Ash-Shâffât/37:103 - 105 26

\footnotetext{
${ }^{24}$ Tim Penterjemah Departemen Agama RI, Alquran.........., h. 724 - 725

${ }^{25}$ Abdul Malik Kari Amrullah, Tafsir........, Juz 2, h.141-144

${ }^{26}$ Tim Penterjemah Departemen Agama RI, Alquran........., h. 725
}

Jurnal Ilmiah AL-MADRASAH, Vol. 2, No. 2, Januari-Juni 2018 


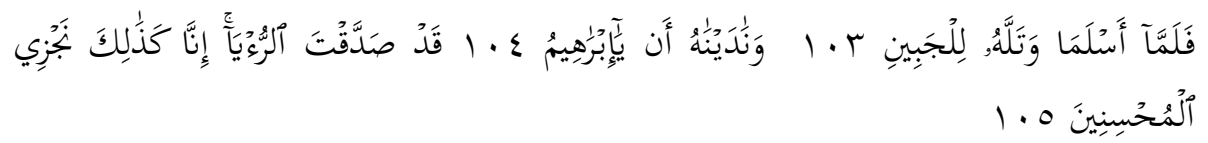

Tanpa ragu dan menunda-nunda, "tatkala keduanya telah berserah diri" secara penuh dan tulus kepada Allah Subhânahu wa Ta'alâ "dan Ia" yakni Ibrâhîm 'Alaihissalâm "membaringkan anaknya atas pelipisnya, sebagaimana binatang yang akan disembelih, ketika itu terbuktilah kesabaran keduanya, pisau yang demikian tajam atas kuasa Allah tidak melukai sang anak sedikit pun, "dan kami” melalui malaikat "memanggilnya; hai Ibrâhîm, sungguh engkau telah membenarkan mimpi" menyangkut penyembelihan anakmu itu dan engkau telah melaksanakannya sekuat kemampuanmu, maka karena itu kami memberimu ganjaran dengan menjadikanmu Imam dan teladan bagi orang-orang yang bertaqwa serta menganugerahkan kepadamu aneka anugerah "sesungguhnya demikianlah kami memberi balasan kepada al-muhsinin. ${ }^{27}$

Q.S. Ash-Shâffât//37:106 28

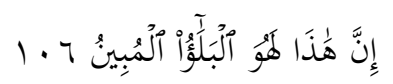

Diperintahkan untuk menyembelih dan disuruh dikurbankan dalam mimpi dan perintah itu dilaksanakan karena nabi Ibrâhîm dan anaknya sama-sama menyerah(aslama) tidak takut menghadapi maut, karena maut untuk melaksanakan perintah ilahi adalah maut yang mulia. Maka Allah menjelaskan ayah dan anak adalah minal muhsinin termasuk orang-orang yang hidupnya berbuat kebajikan ${ }^{29}$.

${ }^{27}$ M. Quraish Shihab, Tafsir ........., V. 11, h. 281-282

${ }^{28}$ Tim Penterjemah Departemen Agama RI, Alquran.........., h. 725

${ }^{29}$ Abdul Malik Karim Amrullah, Tafsir......., Juz 23, h. 144

Jurnal Ilmiah AL-MADRASAH, Vol. 2, No. 2, Januari-Juni 2018 
Q.S. Ash-Shâffât//37:1070

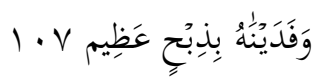

Tangan nabi Ibrâhîm telah ditahan oleh jibril sehingga pisau yang tajam itu tidak sampai ke atas leher Ismail maka datanglah seekor domba besar sebagai ganti Ismail. ${ }^{31}$

Q. S. Ash-Shâffât//37:108 - 109 32

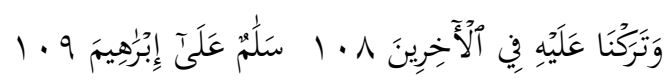

Karena keshalehan yang luar biasa Allah mengangkat tinggi derajat Nabi Ibrâhîm Bukan saja ia dikenang pada zamannya namun menjamin sampai zaman yang akan datang dan tidak dijelaskan sampai mana ia akan dikenang mungkin sampai akhir zaman. ${ }^{33}$

Q.S, Ash-Shâffât//37:110 34

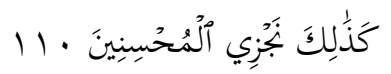

Demikianlah kami (Allah) menghindarkan orang-orang yang mentaati kami dari berbagai macam hal yang tidak disukai dan dari kesusahan. Dan kami jadikan bagi mereka kelapangan dan jalan keluar urusan mereka ${ }^{35}$

Q.S. Ash-Shâffât/37:111 - $112^{36}$

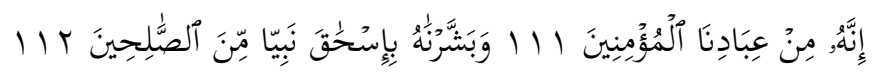

Sesungguhnya Ia Termasuk hamba-hamba Kami yang beriman" "Dan kami beri dia kabar gembira dengan (kelahiran) Ishaq, seorang Nabi yang termasuk orang-orang shalih".

\footnotetext{
${ }^{30}$ Tim Penterjemah Departemen Agama RI, Alquran ........., h. 725

${ }^{31}$ Abdul Malik Karim Amrullah, Tafsir.........., Juz 23, h. 145

32 Tim Penterjemah Departemen Agama RI, Alquran .........., h. 725

${ }^{33}$ Ibnu Katsir, Tafsirul........., jilid 7, h. 32

${ }^{34}$ Tim Penterjemah Departemen Agama RI, Alquran ......, h. 725

${ }^{35}$ Ibnu Katsir, Tafsirul........., Jilid 7, h. 33

${ }^{36}$ Tim Penterjemah Departemen Agama RI, Alquran........., h. 725 - 726
}

Jurnal Ilmiah AL-MADRASAH, Vol. 2, No. 2, Januari-Juni 2018 
Dari uraian diatas dapat disimpulkan bahwa ada beberapa sifat yang harus diteladani, yaitu:

Pertama Cinta. Cinta adalah kesadaran diri, perasaan jiwa dan dorongan hati yang menyebabkan seseorang terpaut hatinya kepada apa yang dicintainya dengan penuh semangat dan rasa kasih saying. Cinta dengan pengertian demikian sudah merupakan fitrah yang dimiliki setiap orang. Islam tidak hanya mengakui keberadaan cinta itu pada diri manusia, tetapi juga mengaturnya sehingga terwujud dengan mulia. Bagi seorang mukmin cinta pertama dan utama sekali diberikan kepada Allah Subhânahu wa Ta'alâ. Allah lebih dicintainya dari pada segalanya. ${ }^{37}$

Kedua Ridha. Ridha terhadap ketentuan Allah Subhânahu wa Ta'alâ artinya menerima semua kejadian yang menimpa dirinya dengan lapang dada, menghadapi dengan tabah, ridha, tidak merasa kesal maupun berputus asa. $^{38}$

Ketiga Ikhlas. Ikhlas termasuk akhlak yang penting pula, Ikhlas adalah amal kebajikan yang dilaksanakan semata-mata karena Allah, yakni semata-mata karena mengharap keridhaanNya, itulah yang disebut beramal dengan ikhlas. Ikhlas itulah ruh amal, amal kebajikan, amal ibadah yang ditunaikan seseorang yang tidak disertai ikhlas, maka amal yang demikian itulah, amal yang tidak mempunyai ruh. ${ }^{39}$ Ikhlas juga syarat diterimanya amal ibadah.

Keempat Husnuzhan. Menjadikan setiap nikmat maupun ujian di dunia adalah kehendak Allah Subhanahu wa Ta'ala yang kita tidak tau rahasia dibalik keduanya, makanya dianjurkan husnuzhan kepada Allah Subhânahu wa Ta'alâ. 2006), h. 24

37 Yunahar Ilyas, Kuliah Akhlak, Cet. VIII, (Yogyakarta: Pustaka Pelajar,

38 Imam Ghazali, Mukasyafatul Qulub diterjemahkan oleh Labib MZ (Surabaya: Bintang Usaha Jaya Surabaya, 2002), h. 69

${ }^{39}$ Hasbi Ash-Shiddieqy, Al-Islam......, h. 394

Jurnal Ilmiah AL-MADRASAH, Vol. 2, No. 2, Januari-Juni 2018 


\section{Ikhtiar, Tawakkal dan Doa Nabi Ibrâhîm 'Alaihissalâm dalam Menjalankan Perintah dan Larangan Allah Subhânahu wa Ta'alâ.}

Allah Subhânahu wa Ta'alâ telah menjadikan Nabi Ibrâhîm 'Alaihissalâm sebagai Imam (pemimpin) seluruh Ahli Tauhid di zamannya hingga hari kiamat, sebagai panutan untuk seluruh manusia jamannya hingga hari kiamat agar manusia selalu meng-Esakan Allah Subhânahu wa Ta'alâ. Ayat tentang Nabi Ibrâhîm 'Alaihissalâm adalah imam para ahli tauhid yang terdapat dalam Q.S. Al-baqarah/2: $124 .^{40}$

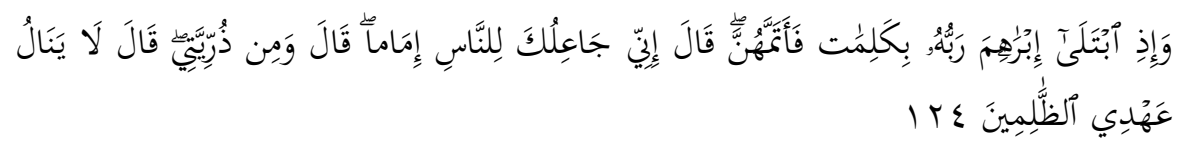

Allah mengingatkan akan kemuliaan Nabi Ibrâhîm 'Alaihissalâm, kekasihNya. "dan ingatlah ketika Nabi Ibrâhîm diuji Rabb-nya dengan beberapa kalimat (perintah dan larangan)". Artinya, wahai Muhammad Shallallâhu 'alaihi Wasallam katakanlah kepada orang-orang musyrik dan Ahlul Kitab yang mengaku sebagai penganut agama Nabi Ibrâhîm padahal mereka tidak mengikuti agama itu. Bahwa yang berada pada agama Nabi Ibrâhîm dan tegak diatasnya adalah engkau dan orang-orang Mukmin bersamamu, maka ceritakanlah kepada mereka ujian yang ditimpakan Allah kepada Nabi Ibrâhîm berupa berbagai perintah dan larangan. ${ }^{41}$

Kemudian Nabi Ibrâhîm menunaikannya.” Maksudnya, maka Nabi Ibrâhîm pun menjalankan semuanya itu, selanjutnya Allah berfirman "Sesungguhnya Aku akan menjadikan Imam bagi seluruh Umat manusia" yaitu sebagai balasan atas apa yang telah dikerjakannya. Karena Ia telah menjalankan perintah dan meninggalkan laranganNya, maka Allah menjadikannya sebagai panutan dan imam bagi manusia yang selalu diikuti jejaknya.

Semua yang didapat Nabi Ibrâhîm tidak cuma-cuma. Beliau mendapatkan semuanya dengan perjuangan yang amat sangat, dimana ketika

\footnotetext{
${ }^{40}$ Tim Penterjemah Departemen Agama RI, Alquran........., h. 124

${ }^{41}$ Ibnu Katsir, Tafsirul........., Jilid 1, h. 405-411
} 
beliau masih belia harus berdakwah kepada kaumnya yang lalim bahkan kepada ayahnya sendiri. Ketika usia uzur dan mengharapkan keturunan, setelah dapat keturunan malah diperintahkan untuk disembelih. Pantaslah Allah Subhânahu wa Ta'alâ memberikan penghargaan kepada beliau sebagai imam seluruh ahli tauhid berkat ikhtiar, tawakkal dan doa beliau dalam menjalankan perintah dan larangan Allah Subhânahu wa Ta'alâ.

Pertama Usaha/Ikhtiar. Ikhtiar adalah berusaha sungguh-sungguh dengan menempuh jalan yang sesuai dengan kaidah-kaidah ilmu yang berlaku dalam bidang yang diusahakan, dengan disertai doa kepada Allah Subhânahu wa Ta'alâ agar usahanya itu berhasil. Dalam ikhtiar terkandung pesan taqwa, yakni bagaimana kita menuntaskan masalah dengan mempertimbangkan pertama-tama apa yang baik menurut Islam, dan kemudian menjadikannya sebagai pilihan, apapun konsekuensinya dan meskipun tidak popular atau terasa berat.

Kedua Tawakal. Tawakkal adalah menyerah tanpa pamrih sepenuhnya, pasrah dan berpegang teguh pada Allah Subhânahu wa Ta'alâ. Dalam mencari kemaslahatan dan kebaikan, menolak kemudharatan yang menyangkut urusan dunia ataupun akhirat. ${ }^{42}$

Ketiga Doa. Doa adalah permohonan (harapan, permintaan, pujian) kepada Tuhan. Adapun berdoa berarti berarti mengucapkan (memanjatkan) doa kepada Tuhan. ${ }^{43}$ Di balik sikap berserah diri, manusia wajib berdoa dan berusaha saat memiliki tujuan atau rencana yang tengah ditargetkan. Dengan berdoa dan berusaha rintangan dan tantangan akan mudah dilewati. Doa yang berarti permohonan mekanismenya melakukan permohonan langsung kepada Allah Subhânahu wa Ta'alâ agar diberikan kebaikan, keberkahan, kemudahan, kesehatan dan jalan keluar dari kesulitan dan lain-lain.

${ }^{42}$ Ust. Labib MZ, Terjemah Mukasyafatul Qulub (Imam Ghazali), Cet. I, (Surabaya, Bintang Usaha Jaya Surabaya, 2002), h. 41

${ }^{43}$ Tim Prima Pena, Kamus Besar Bahasa Indonesia, (Gitamedia Press), h. 231

Jurnal Ilmiah AL-MADRASAH, Vol. 2, No. 2, Januari-Juni 2018 


\section{ANALISIS ASPEK PENDIDIKAN ISLAM PADA KISAH NABI IBRÂHÎM DALAM ALQURAN}

Dalam implementasi dan fungsi, pendidikan Islam sangat memperhatikan aspek yang mendukung atau unsur yang turut mendukung terhadap tercapainya tujuan dari pendidikan Islam. Adapun unsur-unsur atau lazim disebut faktor-faktor pendidikan yaitu: 1. Tujuan (untuk apa dididik), 2. Peserta didik (siapa yang dididik), 3. Pendidik (siapa yang mendidik), 4. Isi ( apa yang dihantarkan) serta 5. Ruang dan waktu(dimana dan bilamana pendidikan dilangsungkan) ${ }^{44}$.

\section{Tujuan Pendidikan Islam}

Tujuan pendidikan dalam kisah Nabi Ibrâhîm 'Alaihissalâm yaitu menjadi imam dan teladan bagi yang lain serta menjadi muslim yang taat dan patuh kepada Allah Subhânahu wa Ta'alâ. Firman Allah Subhânahu wa Ta'alâ dalam Q.S. Al-baqarah/2: $132^{45}$

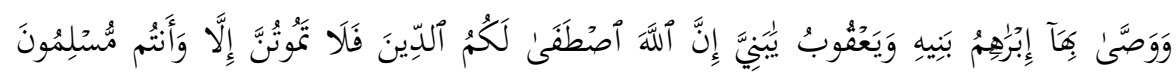

Inilah tujuan pendidikan dalam konsep Nabi Ibrâhîm 'Alaihissalâm berikut juga anak-anak beliau yang juga menjadi nabi, mereka juga didorong untuk mendidik anak-anak mereka dengan pendidikan Islam dan jangan sampai mereka lepas dari agama tercinta ini.

Jika tugas manusia dalam kehidupan ini demikian penting, pendidikan harus memiliki tujuan yang sama dengan tujuan penciptaan manusia. Bagaimanapun, pendidikan Islam sarat dengan pengembangan nalar dan penataan perilaku serta emosi manusia dengan landasan dinul Islam. Dengan demikian, tujuan pendidikan Islam adalah merialisasikan

${ }^{44}$ Ibid, h. 14

${ }^{45}$ Tim Penterjemah Departemen Agama RI, Alquran dan Terjemah, (Semarang, PT. Tanjung Mas Inti;1992), h. 34

Jurnal Ilmiah AL-MADRASAH, Vol. 2, No. 2, Januari-Juni 2018 
penghambaan kepada Allah dalam kehidupan manusia, baik secara individual maupun secara sosial ${ }^{46}$.

\section{Peserta Didik}

Peserta didik dalam pendidikan Islam ialah setiap manusia yang sepanjang hayatnya selalu berada dalam perkembangan. Jadi, bukan hanya anak-anak yang sedang dalam pengasuhan dan pengasihan orang tuanya, bukan pula hanya anak-anak dalam usia sekolah ${ }^{47}$.

Nabi Ibrâhîm 'Alaihissalâm Mendidik dan berdakwah kepada semua lapisan dan dengan berbagai jenis dan latar belakang, serta beragam metode yang digunakan. Adapun peserta didik yang pertama dan utama adalah keluarga beliau sendiri, yaitu anak dan istri, kemudian orangtua baru kemudian kaumnya. Pendidikan keluarga menjadi prioritas pertama sebelum ke yang lain sebagaimana firman Allah dalam Q.S. At-tahrîm/66: 6.

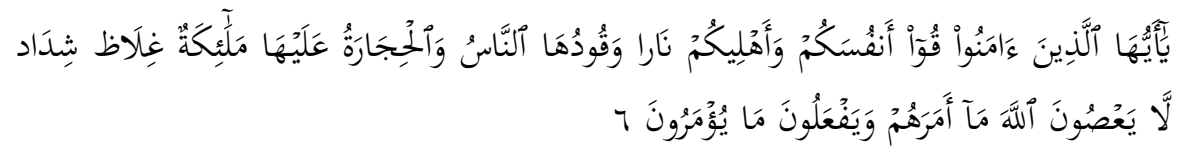

Maka Nabi Ibrâhîm 'Alaihissalâm memulai dari keluarga besarnya, lalu umatnya, tergambar dalam beberapa ayat Allah Subhânahu wa Ta'alâ. Dari ayat diatas Nabi Ibrâhîm 'Alaihissalâm mendahulukan keluarganya sebelum kemudian masyarakat dan umatnya secara umum untuk didakwahi dan dilakukan proses penyadaran dan pendidikan.

\section{Pendidik}

Pendidik berarti juga orang dewasa yang bertanggung jawab memberi pertolongan pada peserta didiknya dalam perkembangan jasmani dan rohannya, agar mencapai tingkat kedewasaan, mampu berdiri sendiri dan mmemenuhi tugasnya sebagai hamba dan khalifah Allah Subhânahu wa

\footnotetext{
${ }^{46}$ Abdurrahman An Nahlawi, Pendidikan Islam di Rumah, Sekolah dan Masyarakat,(Jakarta: Gema Insani, 1995) h.117

${ }^{47}$ Hery Noer Aly, Ilmu ........., h. 113

Jurnal Ilmiah AL-MADRASAH, Vol. 2, No. 2, Januari-Juni 2018 
Ta'alâ. Dan mampu melakukan tugas sebagai makhluk sosial dan sebagai makhluk individu yang mandiri ${ }^{48}$.

Nabi Ibrâhîm 'Alaihissalâm berperan sebagai pendidik langsung dalam menyampaikan ajaran tauhid kepada umatnya. Ada banyak sifat yang telah dicontohkan oleh Nabi Ibrâhîm 'Alaihissalâm. Sebagai seorang nabi sebagai pendidik yang bias kita jadikan pelajaran dalam mendidik anak anak kita dan juga murid murid kita semua.

\section{Isi / Materi Pendidikan}

Istilah materi pendidikan berarti mengorganisir bidang ilmu pengetahuan yang membentuk basis aktivitas lembaga pendidikan, bidangbidang ilmu pengetahuan ini satu dengan lainnya dipisah-pisah namun merupakan satu kesatuan terpadu. Materi pendidikan harus mengacu pada tujuan, bukan sebaliknya tujuan mengarah kepada suatu materi, oleh karenanya materi pendidikan tidak boleh berdiri sendiri terlepas dari kontrol tujuannya. Adapun isi/materi pendidikan Nabi Ibrahim yaitu;

Tauhid, Pendidikan merupakan hal yang penting bagi kehidupan manusia. Secara kodrati manusia membutuhkan pendidikan. Salah satu pendidikan yang paling dasar ditanamkan adalah pendidikan keimanan dalam bentuk pendidikan Tauhid, karena pada dasarnya manusia memiliki fitrah berupa keimanan kepada Allah yang dilahirkan dengan dibekali fitrah untuk beragama tauhid. Begitu pula para rasul dalam menyampaikan risalahnya untuk menanamkan tauhid ke dalam jiwa umatnya, mengajak mereka supaya beriman kepada Allah, menyembah, mengabdi, dan berbakti kepada-Nya dengan melarang berbuat musyrik kepada-Nya.

Ibadah dan Tazkiyatunnufûs, Keduanya sebagai manifestasi tujuan dan misi setiap manusia untuk menyembah Allah Subhânahu wa Ta'alâ dan selalu melakukan pensucian diri dari penyakit penyakit yang mengotori hati, Sholat, doa, haji, menunaikan nazar, dan semua perintah 2006), h. 88

48 Abdul Mujid, Ilmu Pendidikan Islam (Jakarta:Kencana Prenada Media, 
Allah serta menjauhi larangan-larangannya, serta mengikhlaskan semua ibadah hanya karena Allah. ${ }^{49}$ Suatu permohonan kepada Allah yang dilakukan oleh seorang nabi tentu setelah melakukan ikhtiar yang sudah maksimal, dan sudah melakukan proses pembinaan dan pendidikan sebelumnya, dalam do'a yang dimunajatkan beliau meminta agar Allah memberikan kekuatan kepada mereka untuk tetap istiqamah dan mendirikan sholat. Hati yang bersih dan suci adalah gambaran hasil proses tazkiyatunnufûs yang dilakukan oleh Nabi Ibrâhîm 'Alaihissalâm ${ }^{50}$

Akhlak, Cakupan pembahasan akhlak dalam pendidikan Islam amatlah luas, mencakup akhlak kepada Allah, Rasul kepada orangtua, sesama muslim dan akhlak kepada siapapun juga, Nabi Ibrâhîm 'Alaihissalâm menyampaikan materi akhlak melalui perilaku beliau yang dapat menjadi tauladan bagi kita. Seperti akhlak terhadap orangtua beliau, bagaimana beliau tetap berkata sopan dan mendoakan orangtua beliau walaupun orangtua beliau sudah menolak ajaran yang dibawa Nabi Ibrâhîm 'Alaihissalâm.

\section{Metode Pendidikan}

Metode adalah salah satu bagian dari alat pendidikan yang merupakan faktor pendidikan. Metode merupakan hal yang penting dalam mencapai tujuan pendidikan, tanpa adanya metode, tidak mungkin tujuan pendidikan akan tercapai meskipun metode itu bentuknya sangat sederhana ${ }^{51}$. Dalam dakwah Nabi Ibrâhîm 'Alaihissalâm ada beberapa metode yang dipakai, yaitu:

Metode hikmah merupakan cara menyampaikan materi kepada mad'u dengan menggunakan bahasa yang lembut, santun, dan sesuai dengan tingkat nalar pendengarnya. Penerapan metode hikmah oleh Nabi Ibrâhîm

\footnotetext{
${ }^{49}$ Lihat Firman Allah dalam Q.S. Ibrâhîm/14: 37 dan 40.

${ }^{50}$ Lihat firman Allah dalam Q.S. Ash-shoffât/37:83-84.

${ }^{51}$ Burhanuddin Abdullah, Pendidikan Keimanan (Banjarmasin: Antasari Pers, 2008), h. 163
}

Jurnal Ilmiah AL-MADRASAH, Vol. 2, No. 2, Januari-Juni 2018 
'Alaihissalâm yaitu jawaban Nabi Ibrâhîm 'Alaihissalâm terhadap ancaman bapaknya

Metode mau'izhatul hasanah adalah cara berdakwah kepada masyarakat dengan memberikan pelajaran yang baik. Penggunaan metode ini dalam dakwah Nabi Nabi Ibrâhîm 'Alaihissalâm terlihat dalam dua aspek, yaitu: pertama nasihat yaitu memberi pelajaran dan anjuran serta teguran kepada orang lain secara sadar dan berlaku dalam bentuk berhadapan antara penasehat dan yang dinasehati. Kedua Tabsyîr dan Tanzîr, Tabsyîr adalah cara mengajak orang dengan memberi kabar gembira kepada orang yang di ajak dan Tanzîr adalah mengajak orang kepada agama Islam dengan memberi kabar sedih atau ancaman bagi yang tidak mau mengikuti. Metode Mujadalah billati hiya ahsan yaitu dakwah berupa dialog (hiwar) yaitu mendiskusikan suatu objek untuk mendapatkan jawaban.

\section{Lingkungan}

Lingkungan dakwah Nabi Ibrâhîm 'Alaihissalâm dengan kondisi masyarakat yang meyembah berhala beliau tetap gigih memperjuangkan agama tauhid. Lingkungan pendidikan menunjuk kepada situasi dan kondisi yang mengelilingi dan mempunyai pengaruh terhadap perkembangan pribadi. Macam-macam lingkungan dalam Pendidikan Islam.

Lingkungan pertama dalam pendidikan Islam adalah keluarga. Keluarga adalah ikatan laki-laki dengan perempuan berdasarkan hukum perkawinan yang sah. Di dalam keluarga ini lahirlah anak-anak dan di sinilah terjadinya interaksi pendidikan. Keluarga merupakan pendidikan pertama dan utama karena di lingkungan inilah anak mendapatkan pendidikan untuk pertama kalinya. ${ }^{52}$

Sekolah merupakan lembaga pendidikan yang sangat penting sesudah keluarga. Sekolah merupakan lembaga pendidikan yang melaksanakan pembinaan, pendidikan, pengajaran dengan sengaja, teratur

52 Hasan Basri, Beni Ahmad Saebani, Ilmu . Pendidikan Islam Jilid II (Bandung: Pustaka Setia, 2010), h.113

Jurnal Ilmiah AL-MADRASAH, Vol. 2, No. 2, Januari-Juni 2018 
dan terencana. Pendidikan yang berlangsung di sekolah bersifat sistematis, berjenjang, dan dibagi dalam waktu-waktu tertentu yang berlansung dari taman kanak-kanak sampai perguruan tinggi. ${ }^{53}$

Tempat Ibadah yang dimaksud tempat ibadah yaitu seperti musholla, masjid dan sebagainya. Oleh umat Islam, tempat ini biasanya dalam bentuk madrasah diniyah. Dan juga sering diadakan pengajian-peengajian umum seperti untuk peringatan hari-hari besar Islam, tabligh akbar, diskusi, dan seminar. $^{54}$

Masyarakat adalah kumpulan individu dan kelompok yang diikat oleh kesatuan negara, kebudayaan dan agama setiap masyarakat. Masyarakat merupakan lembaga kedua setelah keluarga dan sekolah. Pendidikan ini telah dimulai sejak anak-anak. Dalam lingkungan masyarakat, anak didik akan menemukan berbagai kejadian atau peristiwa yang baru, asing yang baik dan yang buruk.

\section{Penutup}

Ibrah yang bisa diambil dari Kisah Nabi Ibrâhîm 'Alaihissalâm: a. Mencontoh keteladanan Nabi Ibrâhîm 'Alaihissalâm sabar, santun, tegar dan tabah dalam menyampaikan dakwah serta yakin pada kebesaran Allah. b. Selalu membiasakan diri mencintai Allah, ridha atas ketentuan Allah, ikhlas, dan husnuzhan kepada Allah Subhanahu wa Ta'ala. c. Dalam kehidupan kita harus selalu berikhtiar, bertawakkal dan berdoa dalam menjalankan perintah maupun larangan-larangan Allah Subhanahu wa Ta'ala. adapun aspek pendidikan Islam yang terdapat dalam kisah Nabi Ibrâhîm 'Alaihissalâm dalam Alquran adalah: a. Tujuan pendidikan Nabi Ibrâhîm 'Alaihissalâm yaitu menjadi imam para muttaqin dan muslim yang taat dan patuh kepada Allah. b. Peserta didik yaitu kerabat dekat dan kaumnya. c. Pendidik yaitu Nabi Ibrâhîm 'Alaihissalâm langsung menyampaiakan dakwah beliau. d. Materi yang disampaikan Nabi

${ }^{53}$ Bukhari Umar, Ilmu Pendidikan Islam (Jakarta, Hamzah; 2010), h.152

${ }^{54}$ M. Sudiyono, Ilmu.........., h.302

Jurnal Ilmiah AL-MADRASAH, Vol. 2, No. 2, Januari-Juni 2018 
Sari Kumala: Kisah Nabi Ibrâhîm Dalam Alquran (Perspektif Pendidikan Islam)

Ibrâhîm 'Alaihissalâm yaitu tentang Tauhid, Ibadah dan tazkiyatunnufus serta akhlak. e. Metode dalam dakwah Nabi Ibrâhîm 'Alaihissalâm dengan metode hikmah, mau'izatul hasanah dan mujadalah billati hiya ahsan. f. Lingkungan dakwah Nabi Ibrâhîm 'Alaihissalâm dengan kondisi masyarakat yang meyembah berhala beliau tetap gigih memperjuangkan agama tauhid.

Jurnal Ilmiah AL-MADRASAH, Vol. 2, No. 2, Januari-Juni 2018 
Sari Kumala: Kisah Nabi Ibrâhîm Dalam Alquran (Perspektif Pendidikan Islam)

\section{Daftar Pustaka}

Abdullah, Burhanuddin. Pendidikan Keimanan (Banjarmasin: Antasari Pers, 2008).

Al-Munawwar, Said Agil Husin. Aktualisasi Nilai-Nilai al-Qur'an, dalam Sistem Pendidikan Islam (Ciputat: PT. Ciputat Press, 2005).

Aly, Hery. Ilmu Pendidikan Islam (Jakarta: PT. Loogos Wacana Ilmu, 1999).

Amrullah, Abdul Malik Karim. Tafsir al-Azhar Juz VII (Jakarta: Pustaka Panji Mas, 1983)

An Nahlawi, Abdurrahman. Pendidikan Islam di Rumah Sekolah dan Masyarakat (Jakarta: Gema Insani, 1995).

Arifin, M. Ilmu Pendidikan Islam, (Jakarta: Bumi Aksara, 2003).

Ash-Shiddieqy, Hasbi. Sejarah dan Pengantar Ilmu Alquran. Cet. XIV (Jakarta: Bulan Bintang, 1992).

Ash-Shiddieqy, Hasbi. Al-Islam (Jakarta: Bulan Bintang, 1971).

Basri, Hasan dan Beni Ahmadi Saebani. Ilmu Pendidikan Islam Jilid II (Bandung: Pustaka Setia, 2010).

Chirzin, Muhammad. Al-Qur'an dan Ulumul Qur'an (Yogyakarta: Dhani Bhakti Prima Yasa, 2003).

Ghazali, Imam. Mukasyafatuk Qulub diterjemahkan oleh Labib MZ (Surabaya: Bintang Usaha Jaya Surabaya, 2002).

Harahab, Iqbal. Ibrahim Alaihissalam Bapak Semua Agama (Tangerang: Lentera Hati, 2014).

Ilyas, Yunahar. Kuliah Akhlak, Cet. VIII. (Yogyakarta: Pustaka Pelajar, 2006).

Karim, Abdullah. Tanggung Jawab Kolektif Manusia Menurut Alquran. (Banjarmasin: Antasari Press, 2010).

Katsir, Ibnu. Kisah Para Nabi, diterjemahkan oleh Syamsi Hasan, Surabaya: Amelia, t. th).

Katsir, Ibnu. Tafsirul Qur'anil Adzim (Dar Tayyibah, 1999).

Mujid, Abdul. Ilmu Pendidikan Islam (Jakarta: Kencana Prenada Media, 2006).

Quraish Shihab, M. Membumikan al-Qur`an (Bandung: Mizan, 1992)

Quraish Shihab, M. Tafsir Al Misbah; Kesan dan Keserasian Alquran (Jakarta: Lentera Hati, 2011).

Quraish Shihab, M. Wawasan al-Qur'an Tafsir Maudhu'i atas Pelbagai Persoalan Umat. Cet. III (Bandung: Mizan, 1996).

Jurnal Ilmiah AL-MADRASAH, Vol. 2, No. 2, Januari-Juni 2018 
Sari Kumala: Kisah Nabi Ibrâhîm Dalam Alquran (Perspektif Pendidikan Islam)

Sudiyono, M. Ilmu Pendidikan Islam (Jakarta: Rineka Cipta, 2009)

Tim Penterjemah Departemen Agama RI. Alquran dan Terjemahnya (Semarang: PT. Tanjung Mas Inti, 1995)

Tim Penyusun Kamus; Pusat Pembinaan dan Pengembangan Bahasa Departemen Pendidikan dan Kebudayaan, Kamus Besar Bahasa Indonesia Cet. VII (Jakarta: Balai Pustaka, 1996).

Tim Prima Pena. Kamus Besar Bahasa Indonesia (Gita Media Press)

Uhbiyati, Nur. Ilmu Pendidikan Islam. (Bandung: Pustaka Setia, 1997)

Umar, Bukhari. Ilmu Pendidikan Islam (Jakarta: Hamzah, 2010). 
Sari Kumala: Kisah Nabi Ibrâhîm Dalam Alquran (Perspektif Pendidikan Islam)

Jurnal Ilmiah AL-MADRASAH, Vol. 2, No. 2, Januari-Juni 2018 